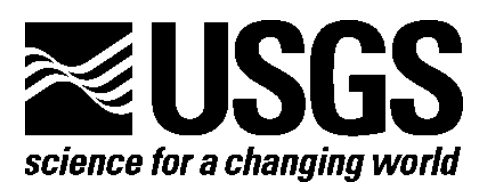

\title{
Publications of the Volcano Hazards Program 2014
}

By Manuel Nathenson

Open-File Report 2016-1060

U.S. Department of the Interior U.S. Geological Survey 


\section{U.S. Department of the Interior \\ SALLY JEWELL, Secretary}

\section{U.S. Geological Survey}

Suzette M. Kimball, Director

U.S. Geological Survey, Reston, Virginia: 2016

For more information on the USGS-the Federal source for science about the Earth, its natural and living resources, natural hazards, and the environment-visit http://www.usgs.gov/ or call 1-888-ASK-USGS (1-888-275-8747).

For an overview of USGS information products, including maps, imagery, and publications, visit http://www.usgs.gov/pubprod/.

Any use of trade, firm, or product names is for descriptive purposes only and does not imply endorsement by the U.S. Government.

Although this information product, for the most part, is in the public domain, it also may contain copyrighted materials as noted in the text. Permission to reproduce copyrighted items must be secured from the copyright owner.

Suggested citation:

Nathenson, Manuel, 2016, Publications of the Volcano Hazards Program 2014: U.S. Geological Survey Open-File Report 2016-1060, 12 p., http://dx.doi.org/10.3133/ofr20161060.

ISSN 2331-1258 (online) 


\section{Publications of the Volcano Hazards Program 2014}

By Manuel Nathenson

The Volcano Hazards Program of the U.S. Geological Survey (USGS) is part of the Natural Hazards activity, as funded by Congressional appropriation. Investigations are carried out by the USGS and with cooperators at the Alaska Division of Geological and Geophysical Surveys, University of Alaska Fairbanks Geophysical Institute, University of Hawai'i Mānoa and Hilo, University of Utah, and University of Washington Geophysics Program. This report lists publications from all of these institutions.

Only published papers and maps are included here; abstracts presented at scientific meetings are omitted. Publication dates are based on year of issue, with no attempt to assign them to a fiscal year. 


\section{Volcano Hazards Program Publications 2014}

Alaska Volcano Observatory, Alaska Division of Homeland Security and Emergency Management, Federal Aviation Administration, National Weather Service, U.S. Air Force Weather Agency, U.S. Coast Guard, and Alaska Department of Environmental Conservation, 2014, Alaska interagency operating plan for volcanic ash episodes, 51 p., accessed June 10, 2014, at http://www.avo.alaska.edu/downloads/reference.php?citid=3996.

Athens, N.D., Ponce, D.A., Jayko, A.S., Miller, M., McEvoy, B., Marcaida, M., Mangan, M.T., Wilkinson, S.K., McClain, J.S., Chuchel, B.A., and Denton, K.M., 2014, Magnetic and gravity studies of Mono Lake, east-central California: U.S. Geological Survey Open-File Report 2014-1043, 14 p., data files, http://dx.doi.org/10.3133/ofr20141043.

Audétat, A., and Lowenstern, J.B., 2014, Melt inclusions, chap. 6 of Scott, S.D., ed., Geochemistry of Mineral Deposits: Treatise on Geochemistry, v. 13, 2nd ed., Elsevier, Amsterdam, p. 143-173.

Bachmann, Olivier, Deering, C.D., Lipman, P.W., and Plummer, Charles, 2014, Building zoned ignimbrites and recycling silicic cumulates - Insight from the $1,000 \mathrm{~km}^{3}$

Carpenter Ridge Tuff, CO: Contributions to Mineralogy and Petrology, v. 167, article $1025,13 \mathrm{p}$.

Bacon, C.R., Dusel-Bacon, Cynthia, Aleinikoff, J.N., and Slack, J.F., 2014, The Late Cretaceous Middle Fork caldera, its resurgent intrusion, and enduring landscape stability in east-central Alaska: Geosphere, v. 10, p. 1432-1455.

Bacon, C.R., Neal, C.A., Miller, T.P., McGimsey, R.G., and Nye, C.J., 2014, Postglacial eruptive history, geochemistry, and recent seismicity of Aniakchak volcano, Alaska Peninsula: U.S. Geological Survey Professional Paper 1810, 74 p., appendixes. [Also available at http://dx.doi.org/10.3133/pp1810.]

Bagnardi, Marco, Poland, M.P., Carbone, Daniele, Baker, Scott, Battaglia, Maurizio, and Amelung, Falk, 2014, Gravity changes and deformation at Kīlauea Volcano, Hawaii, associated with summit eruptive activity, 2009-2012: Journal of Geophysical Research Solid Earth, v. 119, p. 7288-7305.

Banik, T.J., Wallace, P.J., Höskuldsson, Ármann, Miller, C.F., Bacon, C.R., and Furbish, D.J., 2014, Magma-ice-sediment interactions and the origin of lava/hyaloclastite sequences in the Síða formation, South Iceland: Bulletin of Volcanology, v. 76, article $785,19 \mathrm{p}$.

Barron, A.D., Ramsey, D.W., and Smith, J.G., 2014, Database for the geologic map of upper Eocene to Holocene volcanic and related rocks in the Cascade Range, Washington: U.S. Geological Survey Data Series 842, 5 p., data files, http://dx.doi.org/10.3133/ds842.

Beirle, S., Hörmann, C., Penning de Vries, M., Dörner, S., Kern, C., and Wagner, T., 2014, Estimating the volcanic emission rate and atmospheric lifetime of $\mathrm{SO}_{2}$ from space - A case study for Kîlauea volcano, Hawai' $i$ : Atmospheric Chemistry and Physics, v. 14, p. 8309-8322.

Bergfeld, Deborah, Lewicki, J.L., Evans, W.C., Hunt, A.G., Revesz, Kinga, and Huebner, Mark, 2014, Geochemical investigation of the hydrothermal system on Akutan Island, 
Alaska, July 2012: U.S. Geological Survey Scientific Investigations Report 2013-5231, 20 p., http://dx.doi.org/10.3133/sir20135231.

Bergfeld, Deborah, Lowenstern, J.B., Hunt, A.G., Shanks, W.C.P., III, and Evans, W.C., 2014, Gas and isotope chemistry of thermal features in Yellowstone National Park, Wyoming (ver. 1.1, September 2014): U.S. Geological Survey Scientific Investigations Report 2011-5012, 28 p., data files, http://dx.doi.org/10.3133/sir20115012.

Bonasia, Rosanna, Scaini, Chiara, Capra, Lucia, Nathenson, Manuel, Siebe, Claus, Arana-Salinas, Lilia, and Folch, Arnau, 2014, Long-range hazard assessment of volcanic ash dispersal for a Plinian eruptive scenario at Popocatépetl volcano (Mexico)-Implications for civil aviation safety: Bulletin of Volcanology, v. 76, article $789,16 \mathrm{p}$.

Buurman, Helena, Nye, C.J., West, M.E., and Cameron, Cheryl, 2014, Regional controls on volcano seismicity along the Aleutian arc: Geochemistry, Geophysics, Geosystems, v. 15 , p. 1147-1163.

Cameron, C.E., and Nye, C.J., 2014, Preliminary database of Quaternary vents in Alaska: Alaska Division of Geological and Geophysical Surveys Miscellaneous Publication 153, 11 p., database, accessed November 23, 2015, at http://dx.doi.org/10.14509/27357.

Cameron, C.E., Snedigar, S.F., and Nye, C.J., 2014, Alaska Volcano Observatory geochemical database: Alaska Division of Geological and Geophysical Surveys Digital Data Series 8, database, accessed November 23, 2015, at https://www.avo.alaska.edu/geochem/index.php.

Cashman, K.V., and Mangan, M.T., 2014, A century of studying effusive eruptions in Hawai' $i$, chap. 9 of Poland, M.P., Takahashi, T.J., and Landowski, C.M., eds., Characteristics of Hawaiian volcanoes: U.S. Geological Survey Professional Paper 1801, p. 357-394. [Also available at http://dx.doi.org/10.3133/pp1801.]

Chen, Jingyi, Zebker, H.A., Segall, Paul, and Miklius, Asta, 2014, The 2010 slow slip event and secular motion at Kīlauea, Hawai ${ }^{i} i$, inferred from TerraSAR-X InSAR data: Journal of Geophysical Research Solid Earth, v. 119, p. 6667-6683.

Chen, R., Branum, D.M., Wills, C.J., and Hill, D.P., 2014, Scenario earthquake hazards for the Long Valley Caldera-Mono Lake area, east-central California: U.S. Geological Survey Open-File Report 2014-1045 and California Geological Survey Special Report 233, 92 p., http://dx.doi.org/10.3133/ofr20141045.

Clague, D.A., and Sherrod, D.R., 2014, Growth and degradation of Hawaiian volcanoes, chap. 3 of Poland, M.P., Takahashi, T.J., and Landowski, C.M., eds., Characteristics of Hawaiian volcanoes: U.S. Geological Survey Professional Paper 1801, p. 97-146. [Also available at http://dx.doi.org/10.3133/pp1801.]

Clynne, M.A., Christiansen, R.L., Stauffer, P.H., Hendley, J.W., II, and Bleick, Heather, 2014, A sight "fearfully grand"-Eruptions of Lassen Peak, California, 1914 to 1917:

U.S. Geological Survey Fact Sheet 2014-3119, 4 p. [Also available at http://dx.doi.org/10.3133/fs20143119.]

Coombs, M.L., and Vazquez, J.A., 2014, Cogenetic late Pleistocene rhyolite and cumulate diorites from Augustine Volcano revealed by SIMS ${ }^{238} \mathrm{U}^{230} \mathrm{Th}$ dating of zircon, and implications for silicic magma generation by extraction from mush: Geochemistry, Geophysics, Geosystems, v. 15, p. 4846-4865. 
Dawson, Phillip, and Chouet, Bernard, 2014, Characterization of very-long-period seismicity accompanying summit activity at Kīlauea Volcano, Hawai'i: 2007-2013: Journal of Volcanology and Geothermal Research, v. 278-279, p. 59-85.

Delpit, Séverine, Ross, Pierre-Simon, and Hearn, B.C., Jr., 2014, Deep-bedded ultramafic diatremes in the Missouri River Breaks volcanic field, Montana, USA $-1 \mathrm{~km}$ of syneruptive subsidence: Bulletin of Volcanology, v. 76, article 832, 22 p.

Denlinger, R.P., and Moran, S.C., 2014, Volcanic tremor masks its seismogenic sourceResults from a study of noneruptive tremor recorded at Mount St. Helens, Washington: Journal of Geophysical Research Solid Earth, v. 119, p. 2230-2251.

Denlinger, R.P., and Morgan, J.K., 2014, Instability of Hawaiian volcanoes, chap. 4 of Poland, M.P., Takahashi, T.J., and Landowski, C.M., eds., Characteristics of Hawaiian volcanoes: U.S. Geological Survey Professional Paper 1801, p. 149-176. [Also available at http://dx.doi.org/10.3133/pp1801.]

Dennen, R.L., Bursik, M.I., and Roche, O., 2014, Dome collapse mechanisms and blockand-ash flow emplacement dynamics inferred from deposit and impact mark analysis, Mono Craters, CA: Journal of Volcanology and Geothermal Research, v. 276, p. 1-9.

De Siena, L., Thomas, C., Waite, G.P., Moran, S.C., and Klemme, S., 2014, Attenuation and scattering tomography of the deep plumbing system of Mount St. Helens: Journal of Geophysical Research Solid Earth, v. 119, p. 8223-8238.

Downs, D.T., Rowland, J.V., Wilson, C.J.N., Rosenberg, G.S., Leonard, G.S., and Calvert, A.T., 2014, Evolution of the intra-arc Taupo-Reporoa Basin within the Taupo Volcanic Zone of New Zealand: Geosphere, v. 10, p. 185-206.

Downs, D.T., Wilson, C.J.N., Cole, J.W., Rowland, J.V., Calvert, A.T., Leonard, G.S., and Keall, J.M., 2014, Age and eruptive center of the Paeroa Subgroup ignimbrites (Whakamaru Group) within the Taupo Volcanic Zone of New Zealand: Geological Society of America Bulletin, v. 126, p. 1131-1144.

Driedger, Carolyn, Doherty, Anne, Dixon, Cheryl, and Faust, Lisa, coordinators, 2005, Living with a volcano in your backyard-An educator's guide with emphasis on Mount Rainier (ver. 2.0, December 2014): U.S. Geological Survey General Information Product 19, 716 p., http://pubs.usgs.gov/gip/19/.

Eychenne, Julia, Houghton, B.F., Swanson, D.A., Carey, R.J., and Swavely, Lauren, 2014, Dynamics of an open basaltic magma system - The 2008 activity of the Halema'uma'u Overlook vent, Kīlauea Caldera: Earth and Planetary Science Letters, v. 409, p. 49-60.

Fleck, R.J., and Calvert, A.T., 2014, Modified expression for bulb-tracer depletionEffect on argon dating standards: Geochemistry, Geophysics, Geosystems, v. 15, p. 1657-1662.

Fleck, R.J., Hagstrum, J.T., Calvert, A.T., Evarts, R.C., and Conrey, R.M., 2014, ${ }^{40} \mathrm{Ar} /{ }^{39} \mathrm{Ar}$ geochronology, paleomagnetism, and evolution of the Boring volcanic field, Oregon and Washington, USA: Geosphere, v. 10, p. 1283-1314.

Gaunt, H.E., Sammonds, P.R., Meredith, P.G., Smith, Rosanna, and Pallister, J.S., 2014, Pathways for degassing during the lava dome eruption of Mount St. Helens 2004-2008: Geology, v. 42, p. 947-950.

George, D.L., and Iverson, R.M., 2014, A depth-averaged debris-flow model that includes the effects of evolving dilatancy-II. Numerical predictions and experimental 
tests: Proceedings of the Royal Society, ser. A, v. 470, 20130820,

http://dx.doi.org/10.1098/rspa.2013.0820.

Gunawan, Hendra, Pallister, John, and Caudron, Corentin, 2014, Multidisciplinary

monitoring experiments at Kawah Ijen volcano - Cities on Volcanoes "Wet

Volcanoes" Workshop; Yogyakarta, Indonesia, 14-21 Sept. 2014: Eos Transactions of the American Geophysical Union, v. 95, p. 447-448.

Haney, M.M., 2014, Backprojection of volcanic tremor: Geophysical Research Letters, v. 41, p. 1923-1928.

Haney, M.M., and Nakahara, H., 2014, Surface wave Green's tensors in the near field:

Bulletin of the Seismological Society of America, v. 104, p. 1578-1586.

Helz, R.T., Clague, D.A., Mastin, L.G., and Rose, T.R., 2014, Electron microprobe analyses of glasses from Kîlauea tephra units, Kîlauea Volcano, Hawaii: U.S. Geological Survey Open-File Report 2014-1090, 24 p., 2 appendixes, http://dx.doi.org/10.3133/ofr20141090.

Helz, R.T., Clague, D.A., Sisson, T.W., and Thornber, C.R., 2014, Petrologic insights into basaltic volcanism at historically active Hawaiian volcanoes, chap. 6 of Poland, M.P., Takahashi, T.J., and Landowski, C.M., eds., Characteristics of Hawaiian volcanoes: U.S. Geological Survey Professional Paper 1801, p. 237-292. [Also available at http://dx.doi.org/10.3133/pp1801.]

Herrick, J.A., Neal, C.A., Cameron, C.E., Dixon, J.P., and McGimsey, R.G., 2014, 2012 Volcanic activity in Alaska-Summary of events and response of the Alaska Volcano Observatory: U.S. Geological Survey Scientific Investigations Report 2014-5160, 82 p., http://dx.doi.org/10.3133/sir20145160.

Hildreth, Wes, Fierstein, Judy, Champion, Duane, and Calvert, Andrew, 2014, Mammoth Mountain and its mafic periphery-A late Quaternary volcanic field in eastern California: Geosphere, v. 10, p. 1315-1365.

Hill, D.P., Bailey, R.A., Hendley, J.W., II, Stauffer, P.H., and Marcaida, Mae, 2014, California's restless giant - the Long Valley Caldera: U.S. Geological Survey Fact Sheet 2014-3056, 2 p. [Also available at http://dx.doi.org/10.3133/fs20143056.]

Hurwitz, Shaul, and Lowenstern, J.B., 2014, Dynamics of the Yellowstone hydrothermal system: Reviews of Geophysics, v. 51, p. 375-411.

Hurwitz, Shaul, Sohn, R.A., Luttrell, Karen, and Manga, Michael, 2014, Triggering and modulation of geyser eruptions in Yellowstone National Park by earthquakes, earth tides, and weather: Journal of Geophysical Research Solid Earth, v. 119, p. 1718-1737. Ingebritsen, S.E., Gelwick, K.D., Randolph-Flagg, N.G., Crankshaw, I.M., Lundstrom, E.A., McCulloch, C.L., Murveit, A.M., Newman, A.C., Mariner, R.H., Bergfeld, D., Tucker, D.S., Schmidt, M.E., Spicer, K.R., Mosbrucker, A., and Evans, W.C., 2014, Hydrothermal monitoring data from the Cascade Range, northwestern United States: U.S. Geological Survey data release, data files, accessed November 24, 2015, at doi:10.5066/F72N5088, http://water.usgs.gov/nrp/cascade-hydrothermal-monitoring/.

Ingebritsen, S.E., and Manga, M., 2014, Earthquakes-Hydrogeochemical precursors:

Nature Geoscience, v. 7, p. 697-698.

Ingebritsen, S.E., Randolph-Flagg, N.G., Gelwick, K.D., Lundstrom, E.A., Crankshaw, I.M., Murveit, A.M., Schmidt, M.E., Bergfeld, D., Spicer, K.R., Tucker, D.S., Mariner, R.H., and Evans, W.C., 2014, Hydrothermal monitoring in a quiescent volcanic arc: Cascade Range, northwestern United States: Geofluids, v. 14, p. 326-346. 
Irons, T.P., Martin, K.E., Finn, C.A., Bloss, B.R., and Horton, R.J., 2014, Using nuclear magnetic resonance and transient electromagnetics to characterize water distribution beneath an ice covered volcanic crater-The case of Sherman Crater Mt. Baker, Washington: Near Surface Geophysics, v. 12, p. 285-296.

Iverson, R.M., 2014, Debris flows: behavior and hazard assessment: Geology Today, v. 30, p. 15-20.

Iverson, R.M., and George, D.L., 2014, A depth-averaged debris-flow model that includes the effects of evolving dilatancy-I. Physical basis: Proceedings of the Royal Society, ser. A, v. 470, 20130819, http://dx.doi.org/10.1098/rspa.2013.0819.

Kasatkina, Ekaterina, Koulakov, Ivan, West, Michael, and Izbekov, Pavel, 2014, Seismic structure changes beneath Redoubt Volcano during the 2009 eruption inferred from local earthquake tomography: Journal of Geophysical Research Solid Earth, v. 119, p. 4938-4954.

Kauahikaua, Jim, and Orlando, Cindy, 2014, Interagency Collaboration on an Active Volcano-A Case Study at Hawai'i Volcanoes National Park, in Santucci, V.L., ed., NPS-USGS Collaboration to support science and resource management in the National Parks: The George Wright Forum, The GWS Journal of Parks, Protected Areas, and Cultural Sites, v. 31, no. 2, p. 149-156, accessed Sept. 2, 2014, http://www.georgewright.org/node/9643.

Kauahikaua, J.P., and Tilling, R.I., 2014, Natural hazards and risk reduction in Hawai'i, chap. 10 of Poland, M.P., Takahashi, T.J., and Landowski, C.M., eds., Characteristics of Hawaiian volcanoes: U.S. Geological Survey Professional Paper 1801, p. 397-427. [Also available at http://dx.doi.org/10.3133/pp1801.]

Klawonn, Malin, Houghton, B.F., Swanson, D.A., Fagents, S.A., Wessel, Paul, and Wolfe, C.J., 2014, Constraining explosive volcanism-Subjective choices during estimates of eruption magnitude: Bulletin of Volcanology, v. 76, article 793, 6 p.

Klawonn, Malin, Houghton, B.F., Swanson, D.A., Fagents, S.A., Wessel, Paul, and Wolfe, C.J., 2014, From field data to volumes - Constraining uncertainties in pyroclastic eruption parameters: Bulletin of Volcanology, v. 76, article 839, 16 p.

Klemetti, E.W., and Clynne, M.A., 2014, Localized rejuvenation of a crystal mush recorded in zircon temporal and composition variation at the Lassen Volcanic Center, northern California: PLoS ONE, v. 9, e113157, 22 p., accessed November 24, 2015, at http://www.plosone.org/article/info\%3Adoi\%2F10.1371\%2Fjournal.pone.0113157.

Lewicki, J.L., and Hilley, G.E., 2014, Multi-scale observations of the variability of magmatic $\mathrm{CO}_{2}$ emissions, Mammoth Mountain, $\mathrm{CA}$, USA: Journal of Volcanology and Geothermal Research, v. 284, p. 1-15.

Lewicki, J.L., Hilley, G.E., Shelly, D.R., King, J.C., McGeehin, J.P., Mangan, M., and Evans, W.C., 2014, Crustal migration of $\mathrm{CO}_{2}$-rich magmatic fluids recorded by treering radiocarbon and seismicity at Mammoth Mountain, CA, USA: Earth and Planetary Science Letters, v. 390, p. 52-58.

Lin, Guoqing, Amelung, Falk, Lavallée, Yan, and Okubo, P.G., 2014, Seismic evidence for a crustal magma reservoir beneath the upper east rift zone of Kilauea volcano, Hawaii: Geology, v. 42, p. 187-190.

Lin, Guoqing, Shearer, P.M., Matoza, R.S., Okubo, P.G., and Amelung, Falk, 2014, Three-dimensional seismic velocity structure of Mauna Loa and Kilauea volcanoes in 
Hawaii from local seismic tomography: Journal of Geophysical Research Solid Earth, v. 119, p. 4377-4392.

Lowenstern, J. B., Evans, W.C., Bergfeld, D., and Hunt, A.G., 2014, Prodigious degassing of a billion years of accumulated radiogenic helium at Yellowstone: Nature, v. 506, no. 7488, p. 355-358.

Lu, Zhong, and Dzurisin, Daniel, 2014, InSAR Imaging of Aleutian volcanoesMonitoring a volcanic arc from space: Heidelberg, Springer-Verlag, 390 p.

Lyons, J.J., Haney, M.M., Fee, David, and Paskievitch, J.F., 2014, Distinguishing high surf from volcanic long-period earthquakes: Geophysical Research Letters, v. 41, p. 1171-1178.

Ma, Lina, Sherrod, D.R., and Scott, W.E., 2014, Digital data for preliminary geologic map of the Mount Hood 30- by 60-minute quadrangle, northern Cascade Range, Oregon: U.S. Geological Survey Data Series 906, data files, http://dx.doi.org/10.3133/ds906.

Mandler, B.E., Donnelly-Nolan, J.M., and Grove, T.L., 2014, Straddling the tholeiitic/calc-alkaline transition-The effects of modest amounts of water on magmatic differentiation at Newberry Volcano, Oregon: Contributions to Mineralogy and Petrology, v. 168, article 1066, 25 p.

Mangan, M.T., Cashman, K.V., and Swanson, D.A., 2014, The dynamics of Hawaiianstyle eruptions - A century of study, chap. 8 of Poland, M.P., Takahashi, T.J., and Landowski, C.M., eds., Characteristics of Hawaiian volcanoes: U.S. Geological Survey Professional Paper 1801, p. 323-354. [Also available at http://dx.doi.org/10.3133/pp1801.]

Marcaida, Mae, Mangan, M.T., Vazquez, J.A., Bursik, Marcus, and Lidzbarski, M.I., 2014, Geochemical fingerprinting of Wilson Creek formation tephra layers (Mono Basin, California) using titanomagnetite compositions: Journal of Volcanology and Geothermal Research, v. 273, p. 1-14.

Mastin, L.G., 2014, Testing the accuracy of a 1-D volcanic plume model in estimating mass eruption rate: Journal of Geophysical Research Atmospheres, v. 119, p. 24742495.

Mastin, L.G., Van Eaton, A.R., and Lowenstern, J.B., 2014, Modeling ash fall distribution from a Yellowstone supereruption: Geochemistry, Geophysics, Geosystems, v. 15, p. 3459-3475.

Matoza, R.S., and Fee, David, 2014, Infrasonic component of volcano-seismic eruption tremor: Geophysical Research Letters, v. 41, p. 1964-1970.

Matoza, R.S., Shearer, P.M., and Okubo, P.G., 2014, High-precision relocation of longperiod events beneath the summit region of Kilauea Volcano, Hawai' $i$, from 1986 to 2009: Geophysical Research Letters, v. 41, p. 3413-3421.

McGimsey, R.G., Maharrey, J.Z., and Neal, C.A., 2014, 2011 Volcanic activity in Alaska-Summary of events and response of the Alaska Volcano Observatory: U.S. Geological Survey Scientific Investigations Report 2014-5159, 50 p., http://dx.doi.org/10.3133/sir20145159.

McGimsey, R.G., Neal, C.A., Girina, O.A., Chibisova, Marina, and Rybin, Alexander, 2014, 2009 volcanic activity in Alaska, Kamchatka, and the Kurile Islands-Summary of events and response of the Alaska Volcano Observatory: U.S. Geological Survey 
Scientific Investigations Report 2013-5213, 125 p.,

http://dx.doi.org/10.3133/sir20135213.

Mosbrucker, A.R., 2014, High-resolution digital elevation model of Mount St. Helens crater and upper North Fork Toutle River basin, Washington, based on an airborne lidar survey of September 2009: U.S. Geological Survey Data Series 904, data files, http://dx.doi.org/10.3133/ds904.

Murphy, Rachel, Thurber, Clifford, Prejean, Stephanie, and Bennington, Ninfa, 2014, Three-dimensional seismic velocity structure and earthquake relocations at Katmai, Alaska: Journal of Volcanology and Geothermal Research, v. 276, p. 121-131.

Nathenson, Manuel, 2014, Publications of the Volcano Hazards Program 2012: U.S. Geological Survey Open-File Report 2014-1147, 10 p., http://dx.doi.org/10.3133/ofr20141147.

Nathenson, Manuel, and Fierstein, Judy, 2014, Spread sheet to calculate tephra volume for exponential thinning: Vhub, 3 p., spreadsheets, accessed November 24, 2015, at https://vhub.org/resources/3716.

Neal, C.A., Herrick, J., Girina, O.A., Chibisova, M., Rybin, A., McGimsey, R.G., and Dixon, J., 2014, 2010 Volcanic activity in Alaska, Kamchatka, and the Kurile Islands-Summary of events and response of the Alaska Volcano Observatory: U.S. Geological Survey Scientific Investigations Report 2014-5034, 76 p., http://dx.doi.org/10.3133/sir20145034.

Neal, Christina, and Wicks, Chuck, 2014, Foreword, in Lu, Zhong, and Dzurisin, Daniel, InSAR Imaging of Aleutian volcanoes: Monitoring a volcanic arc from space: Heidelberg, Springer-Verlag, p. ix $-\mathrm{X}$.

Newhall, Chris, Frenzen, Peter, and Driedger, Carolyn, 2014, Mount St. Helens, Washington, USA, in Erfurt-Cooper, Patricia, ed., Volcanic Tourist Destinations: Springer-Verlag, Berlin, p. 201-208.

Ohlendorf, S.J., Thurber, C.H., Pesicek, J.D., and Prejean, S.G., 2014, Seismicity and seismic structure at Okmok Volcano, Alaska: Journal of Volcanology and Geothermal Research, v. 278-279, p. 103-109.

Okubo, P.G., Nakata, J.S., and Koyanagi, R.Y., 2014, The evolution of seismic monitoring systems at the Hawaiian Volcano Observatory, chap. 2 of Poland, M.P., Takahashi, T.J., and Landowski, C.M., eds., Characteristics of Hawaiian volcanoes: U.S. Geological Survey Professional Paper 1801, p. 67-94. [Also available at http://dx.doi.org/10.3133/pp1801.]

Old Faithful Science Review Panel, 2014, Hydrogeology of the Old Faithful area, Yellowstone National Park, Wyoming, and its relevance to natural resources and infrastructure. U.S. Geological Survey Open-File Report 2014-1058, 28 p., http://dx.doi.org/10.3133/ofr20141058.

Orr, T.R., 2014, The June-July 2007 collapse and refilling of Pu'u ' $\bar{O}^{‘} \bar{o}$ Crater, Kīlauea Volcano, Hawai'i: U.S. Geological Survey Scientific Investigations Report 2014-5124, 15 p., http://dx.doi.org/10.3133/sir20145124.

Pardo, Natalia, Cronin, S.J, Wright, H.M.N., Schipper, C.I, Smith, Ian, and Stewart, Bob, 2014, Pyroclast textural variation as an indicator of eruption column steadiness in andesitic Plinian eruptions at Mt. Ruapehu: Bulletin of Volcanology, v. 76, article 822, $19 \mathrm{p}$. 
Parker, A.L., Biggs, Juliet, and Lu, Zhong, 2014, Investigating long-term subsidence at Medicine Lake Volcano, CA, using multitemporal InSAR: Geophysical Journal International, v. 199, p. 844-859.

Patrick, M.R., and Delparte, Donna, 2014. Tracking dramatic changes at Hawaii's only alpine lake: EOS Transactions of the American Geophysical Union, v. 95, p. 117-118.

Patrick, M.R., Orr, Tim, Antolik, Loren, Lee, Lopaka, and Kamibayashi, Kevan, 2014, Continuous monitoring of Hawaiian volcanoes with thermal cameras: Journal of Applied Volcanology, v. 3, no. 1, 19 p.

Pierson, T.C., and Major, J.J., 2014, Hydrogeomorphic effects of explosive volcanic eruptions on drainage basins, in Jeanloz, Raymond, and Freeman, K.H., eds., Annual Review of Earth and Planetary Sciences, v. 42, p. 469-507.

Pierson, T.C., Wood, N.J., and Driedger, C.L., 2014, Reducing risk from lahar hazardsConcepts, case studies, and roles for scientists, in Lindsay, Jan, Neal, Christina, Sandri, Laura, and Wilson, Thomas, eds., The application of volcanology research to emergency management: Journal of Applied Volcanology, v. 3, no. 16, 25 p.

Pinel, V., Poland, M.P., and Hooper, A., 2014, Volcanology-Lessons learned from Synthetic Aperture Radar imagery: Journal of Volcanology and Geothermal Research, v. 289, p. 81-113.

Poland, M.P., 2014, Time-averaged discharge rate of subaerial lava at Kîlauea Volcano, Hawai'i, measured from TanDEM-X interferometry-Implications for magma supply and storage during 2011-2013: Journal of Geophysical Research Solid Earth, v. 119, p. 5464-5481.

Poland, M.P., 2014, Contrasting volcanism in Hawai'i and the Galápagos, in Harpp, K.S., Mittelstaedt, E., d'Ozouville, N., and Graham D.W., eds., The Galápagos: A Natural Laboratory for the Earth Sciences: Hoboken, New Jersey, John Wiley and Sons, Inc., American Geophysical Union Geophysical Monograph 204, p. 5-26.

Poland, M.P., and Orr, T.R., 2014, Identifying hazards associated with lava deltas: Bulletin of Volcanology, v. 76, article 880, 10 p.

Poland, M.P., Miklius, Asta, and Montgomery-Brown, E.K., 2014, Magma supply, storage, and transport at shield-stage Hawaiian volcanoes, chap. 5 of Poland, M.P., Takahashi, T.J., and Landowski, C.M., eds., Characteristics of Hawaiian volcanoes: U.S. Geological Survey Professional Paper 1801, p. 179-234. [Also available at http://dx.doi.org/10.3133/pp1801.]

Poland, M.P., Takahashi, T.J., and Landowski, C.M., eds., 2014, Characteristics of Hawaiian volcanoes: U.S. Geological Survey Professional Paper 1801, 429 p. [Also available at http://dx.doi.org/10.3133/pp1801.]

Preece, S.J., McGimsey, R.G., Westgate, J.A., Pearce, N.J.G., Hart, W.K., and Perkins, W.T., 2014, Chemical complexity and source of the White River Ash, Alaska and Yukon: Geosphere, v. 10, p. 1020-1042.

Prejean, S.G., and Haney, M.M., 2014, Shaking up volcanoes: Science, v. 345, no. 6192, p. 39.

Robinson, J.E., 2014, Digital topographic data based on lidar survey of Mount Shasta Volcano, California, July-September 2010: U.S. Geological Survey Data Series 852, maps, data files, http://dx.doi.org/10.3133/ds852. 
Roman, D.C., and Power, J.A., 2014, Grand challenges in U.S. volcano seismology: IA VCEI News, no. 3-4, p. 31-33, accessed November 24, 2015, at http://www.iavcei.org/.

Schaefer, J.R., Cameron, C.E., and Nye, C.J., 2014, Historically active volcanoes of Alaska: Alaska Division of Geological and Geophysical Surveys Miscellaneous Publication 133, v. 1.2, 1 sheet, scale 1:3,000,000, accessed November 24, 2015, at http://www.dggs.alaska.gov/pubs/id/20181.

Schilling, S.P., 2014, Laharz py-GIS tools for automated mapping of lahar inundation hazard zones: U.S. Geological Survey Open-File Report 2014-1073, 78 p., http://dx.doi.org/10.3133/ofr20141073.

Segall, Paul, and Anderson, Kyle, 2014, Volcanology_Look up for magma insights:

Nature Geoscience, v. 7, no. 3, p. 168-169.

Sherrod, D.R., and Wills, B.B., 2014, Debris flow from 2012 failure of moraine-dammed lake, Three Fingered Jack volcano, Mount Jefferson Wilderness, Oregon: U.S. Geological Survey Scientific Investigations Report 2014-5208, 13 p., http://dx.doi.org/10.3133/sir20145208.

Sides, I., Edmonds, M., Maclennan, J., Houghton, B.F., Swanson, D.A., and SteeleMacInnis, M.J., 2014, Magma mixing and high fountaining during the 1959 Kîlauea Iki eruption, Hawai'i: Earth and Planetary Science Letters, v. 400, p. 102-112.

Sides, I.R., Edmonds, M., Maclennan, J., Swanson, D.A., and Houghton, B.F., 2014, Eruption style at Kîlauea Volcano in Hawai' $i$ linked to primary melt composition: Nature Geoscience, v. 7, p. 464-469.

Singer, B.S., Andersen, N.L., Le Mével, Hélène, Feigl, K.L., DeMets, Charles, Tikoff, Basil, Thurber, C.H., Jicha, B.R., Cardona, Carlos, Córdova, Loreto, Gil, Fernando, Unsworth, M.J., Williams-Jones, Glyn, Miller, Craig, Fierstein, Judy, Hildreth, Wes, and Vazquez, Jorge, 2014, Dynamics of a large, restless, rhyolitic magma system at Laguna del Maule, southern Andes, Chile: GSA Today, v. 24, no. 12, p. 4-10.

Sisson, T.W., Salters, V.J.M., and Larson, P.B., 2014, Petrogenesis of Mount Rainier andesite-Magma flux and geologic controls on the contrasting differentiation styles at stratovolcanoes of the southern Washington Cascades: Geological Society of America Bulletin, v. 126, p. 122-144.

Stelling, P.L., Begét, J.E., Gardner, J.E., and Schaefer, J.R., 2014, Preliminary volcanohazard assessment for Fisher volcano, Unimak Island, Alaska: Alaska Division of Geological and Geophysical Surveys Report of Investigation 2014-5, 32 p., 1 plate, scale 1:500,000, accessed November 24, 2015, at http://www.dggs.alaska.gov/pubs/id/29146.

Stovall, W.K., Marcaida, Mae, and Mangan, M.T., 2014, The California Volcano Observatory-Monitoring the State's restless volcanoes: U.S. Geological Survey Fact Sheet 2014-3120, 4 p. [Also available at http://dx.doi.org/10.3133/fs20143120.]

Sutton, A.J., and Elias, Tamar, 2014, One hundred volatile years of volcanic gas studies at the Hawaiian Volcano Observatory, chap. 7 of Poland, M.P., Takahashi, T.J., and Landowski, C.M., eds., Characteristics of Hawaiian volcanoes: U.S. Geological Survey Professional Paper 1801, p. 295-320. [Also available at http://dx.doi.org/10.3133/pp1801.] 
Swanson, D.A., Rose, T.R., Mucek, A.E., Garcia, M.O., Fiske, R.S., and Mastin, L.G., 2014, Cycles of explosive and effusive eruptions at Kīlauea Volcano, Hawai' 1 : Geology, v. 42, p. 631-634.

Thelen, W.A., 2014, Seismic instrumentation plan for the Hawaiian Volcano

Observatory: U.S. Geological Survey Scientific Investigations Report 2014-5179, 43 p., http://dx.doi.org/10.3133/sir20145179.

Tilling, R.I., 2014, Volcanic hazards: Elsevier, reference module in Earth systems and environmental sciences, 18 p., accessed November 25, 2015, at http://dx.doi.org/10.1016/B978-0-12-409548-9.09385-4.

Tilling. R.I., 2014, Volcanic hazards and early warning, in Myers, R.A., ed., Encyclopedia of complexity and systems science, 2nd ed.: New York, Springer Science, 19 p., http://dx.doi.org/10.1007/978-3-642-27737-5_581-2.

Tilling, R.I., Kauahikaua, J.P., Brantley, S.R., and Neal, C.A., 2014, The Hawaiian Volcano Observatory-A natural laboratory for studying basaltic volcanism, chap. 1 of Poland, M.P., Takahashi, T.J., and Landowski, C.M., eds., Characteristics of Hawaiian volcanoes: U.S. Geological Survey Professional Paper 1801, p. 1-64. [Also available at http://dx.doi.org/10.3133/pp1801.]

Uhrich, M.A., Kolasinac, Jasna, Booth, P.L., Fountain, R.L., Spicer, K.R., and Mosbrucker, A.R., 2014, Correlations of turbidity to suspended-sediment concentration in the Toutle River Basin, near Mount St. Helens, Washington, 2010-11: U.S.

Geological Survey Open-File Report 2014-1204, 30 p., http://dx.doi.org/10.3133/ofr20141204.

Vandemeulebrouck, Jean, Sohn, R.A., Rudolph, M.L., Hurwitz, Shaul, Manga, Michael, Johnston, M.J.S., Soule, S.A., McPhee, Darcy, Glen, J.M.G., Karlstrom, Leif, and Murphy, Fred, 2014, Eruptions at Lone Star geyser, Yellowstone National Park, USA - 2. Constraints on subsurface dynamics: Journal of Geophysical Research, v. 119, p. 8667-8687.

Vaughan, R.G., Heasler, Henry, Jaworowski, Cheryl, Lowenstern, J.B., and Keszthelyi, L.P., 2014, Provisional maps of thermal areas in Yellowstone National Park, based on satellite thermal infrared imaging and field observations: U.S. Geological Survey Scientific Investigations Report 2014-5137, 22 p., http://dx.doi.org/10.3133/sir20145137.

Vidale, J.E., Schmidt, D.A., Malone, S.D., Hotovec-Ellis, A.J., Moran, S.C., Creager, K.C., and Houston, H., 2014, Deep long-period earthquakes west of the volcanic arc in Oregon-Evidence of serpentine dehydration in the fore-arc mantle wedge:

Geophysical Research Letters, v. 41, p. 370-376.

Vita, F., Kern, C., and Inguaggiato, S., 2014, Development of a portable active long-path differential optical absorption spectroscopy system for volcanic gas measurements: Journal of Sensors and Sensor Systems, v. 3, p. 355-367.

Wallace, K.L., Coombs, M.L., Hayden, L.A., and Waythomas, C.F., 2014, Significance of a near-source tephra-stratigraphic sequence to the eruptive history of Hayes Volcano, south-central Alaska: U.S. Geological Survey Scientific Investigations Report 2014-5133, 32 p., http://dx.doi.org/10.3133/sir20145133.

Waythomas, C.F., 2014, Water, ice and mud - Lahars and lahar hazards at ice- and snowclad volcanoes: Geology Today, v. 30, no. 1, p. 34-39. 
Waythomas, C.F., Haney, M.M., Fee, David, Schneider, D.J., and Wech, Aaron, 2014, The 2013 eruption of Pavlof Volcano, Alaska-A spatter eruption at an ice- and snowclad volcano: Bulletin of Volcanology, v. 76, article 862, 12 p.

Wech, A.G., and Bartlow, N.M., 2014, Slip rate and tremor genesis in Cascadia:

Geophysical Research Letters, v. 41, p. 392-398.

Werner, Cynthia, Bergfeld, Deborah, Farrar, C.D., Doukas, M.P., Kelly, P.J., and Kern, Christoph, 2014, Decadal-scale variability of diffuse $\mathrm{CO}_{2}$ emissions and seismicity revealed from long-term monitoring (1995-2013) at Mammoth Mountain, California, USA: Journal of Volcanology and Geothermal Research, v. 289, p. 51-63.

Wilcox, A.C., O’Connor, J.E., and Major, J.J., 2014, Rapid reservoir erosion, hyperconcentrated flow, and downstream deposition triggered by breaching of $38 \mathrm{~m}$ tall Condit Dam, White Salmon River, Washington: Journal of Geophysical Research Earth Surface, v. 120, p. 1376-1394.

Wilkinson, Stuart, Hill, D.P., Langbein, J.O., Lisowski, Mike, and Mangan, Margaret, 2014, Long Valley Caldera 2003 through 2014-Overview of low level unrest in the past decade: U.S. Geological Survey Open-File Report 2014-1222, 1 sheet, http://dx.doi.org/10.3133/ofr20141222.

Worden, Anna, Dehn, Jonathan, and Webley, Peter, 2014, Frequency based satellite monitoring of small scale explosive activity at remote North Pacific volcanoes: Journal of Volcanology and Geothermal Research, v. 286, p. 1-14.

Wright, H.M., and Cashman, K.V., 2014, Compaction and gas loss in welded pyroclastic deposits as revealed by porosity, permeability, and electrical conductivity measurements of the Shevlin Park Tuff: Geological Society of America Bulletin, v. 126, p. 234-247.

Wright, T.L., and Klein, F.W., 2014, Two hundred years of magma transport and storage at Kīlauea Volcano, Hawai'i, 1790-2008: U.S. Geological Survey Professional Paper 1806, 240 p., 9 appendixes. [Also available at http://dx.doi.org/10.3133/pp1806.]

Wynn, Jeff, 2014, Gravity, magnetic, and radiometric data for Newberry Volcano, Oregon, and vicinity: U.S. Geological Survey Data Series 830, maps and data files, http://dx.doi.org/10.3133/ds830.

Xu, Guangping, Huang, Shichun, Frey, F.A., Blichert-Toft, Janne, Abouchami, Wafa, Clague, D.A., Cousens, Brian, Moore, J.G., and Beeson, M.H., 2014, The distribution of geochemical heterogeneities in the source of Hawaiian shield lavas as revealed by a transect across the strike of the Loa and Kea spatial trends-East Molokai to West Molokai to Penguin Bank: Geochimica et Cosmochimica Acta, v. 132, p. 214-237.

Yellowstone Volcano Observatory, 2014, Protocols for geologic hazards response by the Yellowstone Volcano Observatory (ver. 2.0, November 2014): U.S. Geological Survey Circular 1351, 16 p., http://dx.doi.org/10.3133/cir1351. 